\title{
LAS LIMITACIONES DE LOS DESPIDOS VINCULADOS A LA COVID-19: CRITERIOS JURISPRUDENCIALES
}

\section{Limitations on dismissals linked to COVID-19: jurisprudential criteria}

\author{
Djamil Tony Kahale Carrillo*
}

Profesor Titular de la Universidad Politécnica de Cartagena, España

\section{RESUMEN}

El RDL 9/2020, de 27 de marzo, por el que se adoptan medidas complementarias en el ámbito laboral para paliar los efectos derivados del COVID-19, dispuso en su artículo 2, entre otras medidas, la denominada "prohibición de despedir». Precepto que ha traído controversias al no indicar de manera expresa las consecuencias de los despidos en pandemia. El presente artículo se centra, por tanto, en una de las cuestiones más polémicas que ha deparado su aplicación en determinar, según los criterios jurisprudenciales de las sentencias menores, la calificación que merecen los despidos producidos vinculados a la COVID-19.

Palabras clave: ERTE, COVID-19, despidos, protección del empleo, improcedencia, nulidad.

\section{ABSTRACT}

RDL 9/2020, of 27 March, adopting complementary measures in the labour field to alleviate the effects derived from COVID-19, provided in its article 2, among other measures, the so-called "probibition of dismissals". This provision has caused controversy as it does not expressly indicate the consequences of dismissals during a pandemic. This article therefore focuses on one of the most controversial issues that has led to its application in determining, according to the jurisprudential criteria of minor judgments, the qualification that dismissals linked to COVID-19 deserve.

Keywords: ERTE, COVID-19, dismissals, employment protection, unfairness, nullity.

\footnotetext{
* Correspondencia a: Djamil Tony Kahale Carrillo. C/ Real, n. ${ }^{0}$ 3, Cartagena (Murcia-España). — djamil.kahale@upct.es https://orcid.org/0000-0002-0266-3380

Cómo citar: Kahale Carrillo, Djamil Tony. (2022). «Las limitaciones de los despidos vinculados a la COVID-19: criterios jurisprudenciales"; Lan Harremanak, 47, 13-40. (https: //doi.org/10.1387/lan-harremanak.23219).
}

Recibido: 24 noviembre, 2021; aceptado: 21 enero, 2022.

ISSN 1575-7048 - elSSN 2444-5819 / (C) 2022 UPV/EHU 


\section{Introducción}

El Consejo de Ministros acordó declarar el estado de alarma ${ }^{1}$, en virtud del Real Decreto 463/2020, de 14 de marzo, con motivo de la crisis sanitaria originada por la pandemia del COVID-192. Posteriormente, aquel Consejo ha aprobado el Real Decreto-ley 8/2020, de 17 de marzo, de medidas urgentes extraordinarias para hacer frente al impacto económico y social del COVID-19 (RDL $8 / 2020)^{3}$, con el fin de arbitrar un conjunto de medidas que permitieran paliar, en cierta medida, la crisis sanitaria, económica y social generada por la pandemia del COVID-19.

Empero, entre las medidas contempladas en esta última norma, se recoge la flexibilización de los Expedientes de Regulación Temporal de Empleo (ERTE), tanto por causa de fuerza mayor, como en el supuesto de los derivados de causas económicas, técnicas, organizativas y de producción, con el fin de intentar paliar los efectos devastadores que esta crisis sanitaria está produciendo en el mercado laboral.

El notable estancamiento que está registrando el mercado laboral, aunado al importante volumen de ERTE presentados, desde la declaración del estado de alarma, ha puesto de relieve la necesidad de que el Gobierno arbitre nuevas medidas e instrumentos que contribuyan a paliar los efectos de la crisis sanitaria sobre los trabajadores. De esta forma, la situación extraordinaria y urgente por la que ha atravesado España ha requerido la adopción de nuevas medidas que respondan de manera adecuada a las necesidades que se derivan de las consecuencias cambiantes de la crisis sanitaria. Que suponen una alteración grave, y sin precedentes, de la vida diaria y que tiene un impacto devastador sobre el mercado laboral; al generar una gran incertidumbre en un amplio colectivo de las personas trabajadoras, que están viendo afectados sus puestos de trabajo, a raíz de la suspensión de un importante volumen de actividades, como consecuencia de la declaración de aquel estado de alarma.

Bajo este contexto, se promulga el Real Decreto-ley 9/2020, de 27 de marzo, por el que se adoptan medidas complementarias, en el ámbito laboral, para paliar los efectos derivados del COVID-19 (RDL 9/2020) ${ }^{4}$ — norma que

${ }^{1}$ Esta obra queda enmarcada dentro de los trabajos de investigación desarrollados por el autor en el Proyecto financiado por la Comunidad Autónoma de la Región de Murcia a través de la convocatoria de Ayudas a proyectos para el desarrollo de investigación científica y técnica por grupos competitivos, incluida en el Programa Regional de Fomento de la Investigación Científica y Técnica (Plan de Actuación 2018) de la Fundación Séneca-Agencia de Ciencia y Tecnología de la Región de Murcia: 20976/PI/18; así como en el proyecto: Bargaining upfront in the digital age (VS/2019/0280), financiado por la Comisión Europea.

2 BOE núm. 67, de 14 de marzo de 2020.

3 BOE núm. 73, de 18 de marzo de 2020.

${ }^{4}$ BOE núm. 86, de 28 de marzo de 2020. 
ha sido tramitada como proyecto de ley, que ahora se entiende como tácitamente sustituida por la Ley 3/2021, de 12 de abril, por la que se adoptan medidas complementarias, en el ámbito laboral, para paliar los efectos derivados del COVID-195-, que persigue establecer aquellos instrumentos tendentes a garantizar la aplicación efectiva de los servicios que resultan esenciales en las circunstancias actuales, al objeto de dar una respuesta adecuada a las necesidades de atención sanitaria y social, que concurren.

Por lo que viene a complementar y detallar algunas de las medidas previstas, en lo atinente a la tramitación de los ERTE, previstas en el RDL 8/2020, concretando el procedimiento de reconocimiento de la prestación contributiva por desempleo, para todas las personas afectadas por procedimientos de suspensión de contratos y reducción de jornada basados en las causas previstas en los artículos 22 y 23. Asimismo, integra otra serie de medidas, en el ámbito laboral, destinadas a paliar los efectos de la crisis de la COVID-19, sobre las personas trabajadoras.

El objeto de este trabajo se circunscribe a las limitaciones de los despidos vinculados a la COVID-19, especialmente a las medidas extraordinarias para la protección del empleo que regula el RDL 9/2020. Dicho en otras palabras, a la fuerza mayor y las causas económicas, técnicas, organizativas y de producción en las que se amparan las medidas de suspensión de contratos y reducción de jornada previstas en los artículos 22 y 23 del RDL8/2020; al establecer que no se podrán entender como justificativas de la extinción del contrato de trabajo ni del despido.

Cuestión que ha tenido varias prórrogas a través de los siguientes instrumentos (Grisolía, 2021): a) Real Decreto-ley 18/2020, de 12 de mayo, de medidas sociales en defensa del empleo (Disp. Final segunda) ${ }^{6}$; b) Real Decretoley $24 / 2020$, de 26 de junio, de medidas sociales de reactivación del empleo y protección del trabajo autónomo y de competitividad del sector industrial (art. 7) ${ }^{7}$; c) Real Decreto-ley 30/2020, de 29 de septiembre, de medidas sociales en defensa del empleo (art. 6) ${ }^{8}$; d) Real Decreto-ley 2/2021, de 26 de enero, de refuerzo y consolidación de medidas sociales en defensa del empleo (art. 3) e) Ley 3/2021, de 12 de abril, por la que se adoptan medidas complementarias, en el ámbito laboral, para paliar los efectos derivados del COVID-19 (art. 2) ${ }^{10}$; f) Real Decreto-ley 11/2021, de 27 de mayo, sobre medidas urgentes para la defensa del empleo, la reactivación económica y la protección de los trabajadores

\footnotetext{
BOE núm. 88, de 13 de abril de 2021.

BOE núm. 134, de 13 de mayo de 2020.

BOE núm. 178, de 27 de junio de 2020.

BOE núm. 259, de 30 de septiembre de 2020.

BOE núm. 23, de 27 de enero de 2021.

10 BOE núm. 88, de 13 de abril de 2021.
} 
autónomos (art. 1) ${ }^{11}$; g) Real Decreto-ley 18/2021, de 28 de septiembre, de medidas urgentes para la protección del empleo, la recuperación económica y la mejora del mercado de trabajo (art. 1) ${ }^{12}$.

Antes de analizar las limitaciones de los despidos vinculados a la COVID-19, se estudiará lo señalado en el artículo 22 y 23 del RDL 8/2020 para una mejor comprensión general de la investigación; es decir, lo concerniente, respectivamente, a las medidas excepcionales en relación con los procedimientos de suspensión de contratos y reducción de jornada por causa de fuerza mayor; y a las medidas excepcionales en relación con los procedimientos de suspensión y reducción de jornada por causa económica, técnica, organizativa y de producción.

La metodología de investigación que se ha llevado a cabo para materializar este estudio se ha basado, fundamentalmente en una revisión normativa. Asimismo, se ha realizado la revisión y el análisis bibliográfico de artículos de revistas jurídicas especializadas, libros, internet, jurisprudencia y bases de datos en relación con el tema. La metodología antes descrita ha sido la idónea para poder llevar a cabo el trabajo, ya que sin la revisión del material legislativo, jurisprudencial y bibliográfico no se hubiese podido materializar.

\section{Medidas excepcionales en relación con los procedimientos de suspensión de contratos y reducción de jornada por causa de fuerza mayor}

El artículo 22 del RDL 8/2020 dispone que las suspensiones de contrato y reducciones de jornada que tengan su causa directa en pérdidas de actividad como consecuencia de la COVID-19, incluida la declaración del estado de alarma, que impliquen suspensión o cancelación de actividades, cierre temporal de locales de afluencia pública, restricciones en el transporte público y, en general, de la movilidad de las personas y/o las mercancías, falta de suministros que impidan gravemente continuar con el desarrollo ordinario de la actividad, o bien en situaciones urgentes y extraordinarias debidas al contagio de la plantilla o la adopción de medidas de aislamiento preventivo decretados por la autoridad sanitaria, que queden debidamente acreditados, tendrán la consideración de provenientes de una situación de fuerza mayor, con las consecuencias que se derivan del artículo 47 del Real Decreto Legislativo 2/2015, de 23 de octubre, por el que se aprueba el texto refundido de la Ley del Estatuto de los Trabajadores $(\mathrm{ET})^{13}$; es decir, a lo concerniente a la «suspensión del contrato o reducción de

\footnotetext{
11 BOE núm. 127, de 28 de mayo de 2021.

12 BOE núm. 233, de 29 de septiembre de 2021.

13 BOE núm. 255, de 24 de octubre de 2015.
} 
jornada por causas económicas, técnicas, organizativas o de producción o derivadas de fuerza mayor».

Por tanto, el ET configura la fuerza mayor como un elemento causal que podrá determinar, cuando se haya constatado, la suspensión o extinción contractual. La diferencia de estos dos últimos radica en sus efectos. Por una parte, en la extinción, la norma exige que aquellos provoquen la imposibilidad definitiva de la prestación de trabajo. Por otra, en la suspensión, se exige exclusivamente que la imposibilidad sea temporal (Blasco, López y Ramos, 2020; 113).

La noción clásica de fuerza mayor laboral ha sido objeto de concreción, como ya se ha señalado, por el aluvión de normativa desde la aparición de la COVID-19. Bajo este contexto, la empresa que decida materializar aquella medida tendría que aplicar las siguientes especialidades, respecto del procedimiento recogido en la normativa reguladora de aquellos expedientes:

a) El procedimiento se iniciará mediante solicitud de la empresa, que se acompañará de un informe relativo a la vinculación de la pérdida de actividad como consecuencia de la COVID-19; así como la correspondiente documentación acreditativa. La empresa deberá comunicar, a su vez, su solicitud a las personas trabajadoras y trasladar el informe anterior y la documentación acreditativa, en caso de existir, a la representación de aquellas.

b) La existencia de fuerza mayor, como causa motivadora de suspensión de los contratos o de la reducción de jornada anteriormente señalada, deberá ser constatada por la autoridad laboral, cualquiera que sea el número de trabajadores afectados.

c) La resolución de la autoridad laboral se dictará en el plazo de cinco días desde la solicitud, previo informe, en su caso, de la Inspección de Trabajo y Seguridad Social y deberá limitarse a constatar la existencia, cuando proceda, de la fuerza mayor alegada por la empresa correspondiendo a esta la decisión sobre la aplicación de medidas de suspensión de los contratos o reducción de jornada, que surtirán efectos desde la fecha del hecho causante de la fuerza mayor.

d) El informe de la Inspección de Trabajo y Seguridad Social, cuya solicitud será potestativa para la autoridad laboral, se evacuará en el plazo improrrogable de cinco días.

En el supuesto de que aquella medida se aplique a las personas socias trabajadoras de cooperativas de trabajo asociado y sociedades laborales incluida en el Régimen General de la Seguridad Social o en algunos de los regímenes especiales que protejan la contingencia de desempleo, será de aplicación el procedimiento especifico previsto en el artículo 2 del Real Decreto 42/1996, de 19 de 
enero, por el que se amplía la protección por desempleo a los socios trabajadores de cooperativas de trabajo asociado en situación de cese temporal o reducción temporal de jornada (RD 42/1996) ${ }^{14}$.

\section{Medidas excepcionales en relación con los procedimientos de suspensión y reducción de jornada por causa económica, técnica, organizativa y de producción}

El artículo 23 del RDL 8/2020 señala que en los casos que la empresa decida la suspensión de contrato o reducción de la jornada por causas económicas, técnicas, organizativas y de producción relacionadas con la COVID-19, se aplicarán las siguientes especialidades, respecto del procedimiento recogido en la normativa reguladora de estos expedientes:

a) En el supuesto de que no exista representación legal de las personas trabajadoras, la comisión representativa de estas para la negociación del periodo de consultas estará integrada por los sindicatos más representativos y representativos del sector al que pertenezca la empresa y con legitimación para formar parte de la comisión negociadora del convenio colectivo de aplicación. La comisión, no obstante, estará conformada por una persona por cada uno de los sindicatos que cumplan dichos requisitos, tomándose las decisiones por las mayorías representativas correspondientes. En caso de no conformarse esta representación, la comisión estará integrada por tres trabajadores de la propia empresa, elegidos conforme a lo recogido en el artículo 41 del ET ${ }^{15}$.

b) El periodo de consultas entre la empresa y la representación de las personas trabajadoras o la comisión representativa seńalada anteriormente no deberá exceder del plazo máximo de siete días.

c) El informe de la Inspección de Trabajo y Seguridad Social, cuya solicitud será potestativa para la autoridad laboral, se evacuará en el plazo improrrogable de siete días. Hay que destacar, no obstante, que en la medida anterior es de cinco días.

De igual manera, que la anterior medida, en el caso de los expedientes de suspensión de contratos y reducción de jornada que afecten a las personas socias

14 BOE núm. 42, de 17 de febrero de 1996. Salvo en lo relativo al plazo para la emisión de resolución por parte de la Autoridad Laboral y al informe de la Inspección de Trabajo y Seguridad Social, que se regirán por lo previsto en los apartados c) y d) del apartado anteriormente señalados.

15 En cualquiera de los supuestos anteriores, la comisión representativa deberá estar constituida en el improrrogable plazo de 5 días. 
trabajadoras de cooperativas de trabajo asociado y sociedades laborales incluidos en el Régimen General de la Seguridad Social o en algunos de los regímenes especiales que protejan la contingencia de desempleo, será de aplicación el procedimiento especifico previsto en el RD 42/1996 ${ }^{16}$.

\section{Criterio jurisprudencial}

De la literalidad del artículo 2 del RDL 9/2020 al indicar que la fuerza mayor y las causas económicas, técnicas, organizativas y de producción en las que se amparan las medidas de suspensión de contratos y reducción de jornada previstas en los artículos 22 y 23 del RDL 8/2020 no se podrán entender como justificativas de la extinción del contrato de trabajo ni del despido; se deduce que la voluntad del legislador es la de impedir las extinciones de los contratos de trabajo durante la crisis sanitaria de la COVID-19 ofreciendo, como mecanismo alternativo, los ERTES.

Por tanto, desde una interpretación finalista de la norma, quedan fuera de estos concretos supuestos, los despidos y las extinciones de contratos de trabajo con fundamento en otras causas. Hay que tener en cuenta que dicho precepto se aplica a todas las empresas, independientemente de que hayan estado o no en situación de regulación de empleo.

La redacción del artículo 2 del RDL 9/2020, no obstante, plantea una serie de cuestiones, dado que deja vacías de contenido a los siguientes asuntos (González, 2020; 337); a las que la Exposición de Motivos de la norma no contiene referencia alguna, por lo que la deja sin fuente de información que podría contribuir a desvelar el verdadero propósito del legislador (González, 2021):

- No queda claro si su aplicación queda asociada exclusivamente a las causas de la COVID-19 para justificar el ERTE o se requiere que el empresario tenga que adoptar las medidas de ajuste.

- Se aplica a las comunicaciones de despido disciplinario fundadas en causas ficticias o por otras causas objetivas para evitar la referencia de la COVID-19 con el fin de desplazar la aplicación del artículo 2 en cuestión.

- La norma no es contraria a derecho en cuanto a la concreción temporal por el legislador de las exigencias para acordar tanto despidos colectivos como despidos objetivos.

—El incumplimiento del precepto determina la nulidad, dado que vulnera una norma imperativa de interés general.

16 En cualquier caso, se regirán por lo previsto en los apartados b) y c) del apartado anterior. 
- El no cumplimiento del artículo en cuestión produce, como efecto, la improcedencia como sucede en los supuestos de cualquier extinción contractual no justificada o sin causa legal.

- Si la medida resulta aplicable, o no, cuando por motivos de la crisis sanitaria finaliza la obra o servicio, subcontrata o se extingue el contrato de puesta a disposición de una Empresa de Trabajo Temporal (Todoli, 2020).

- Se puede descartar que exista la obligación de reposición de las exoneraciones de las cuotas, dado que, por una parte, la norma no señala nada al respecto. Por otra, al entrar en vigor el RDL 9/2020 los ERTES por motivos económicos, técnicos, organizativos o productivos no gozaban de las mismas (Falguera, 2020; 110). En ese sentido, se destaca que, como regla general, en los supuestos de suspensión del contrato o reducción de jornada, la empresa está obligada al ingreso de su aportación. Empero, en los Reales Decretos-leyes 8/2020, de 17 de marzo, 18/2020, de 12 de mayo, y 24/2020 de 26 de junio, se establece, como excepción, que en los ERTE autorizados en base a fuerza mayor temporal vinculada al COVID-19, así como en los expedientes de regulación de empleo por causas económicas, técnicas, organizativas y de producción -ETOP- la empresa, estará exonerada del abono de la aportación empresarial, incluida la cotización para desempleo, Fondo de Garantía Salarial y Formación Profesional en los porcentajes y condiciones previstos en la normativa reguladora citada anteriormente. En el caso de las reducciones de jornada de trabajo, la empresa mantiene la obligación del ingreso de las aportaciones tanto suya como de la persona trabajadora respecto de la parte de la jornada de trabajo en la que se presta la actividad, y queda exonerada del pago de las cuotas de la parte de la jornada de trabajo no realizada.

- Su redacción puede lesionar el artículo 38 de Constitución española $(\mathrm{CE})^{17}$. En tal caso, se debería plantear la cuestión de constitucionalidad correspondiente, y no limitarse a inaplicar esta norma imperativa (López, 2021).

Con relación a esto último se ha indicado que no se lesiona aquel precepto constitucional, dado que admite restricciones en el artículo 35 de la CE. La estabilidad real que ofrece es, por una parte, temporal. Por otra, proporcionada "porque los costes de aquella se socializan en gran medida» (Molina, 2020; 91). Asimismo, se ha indicado que la libertad de empresa se somete a las exigencias de la economía general y, en su caso, de la planificación, por lo que tal derecho constitucional se puede limitar con otros principios o intereses generales, y más en una situación de pandemia, en el que prima la salud de todos los ciudadanos (SJS de Barcelona, núm. 1, de 15 de febrero de 2020. Rec. núm. 283/2020).

17 BOE núm. 311, de 29 de diciembre de 1978. 
Dicho de otra manera, aquel precepto constitucional no legitima que los trabajadores hayan de soportar limitaciones injustificadas de sus derechos fundamentales y libertades públicas ${ }^{18}$. Pero dicha libertad de empresa otorga al empresario un poder organizativo y disciplinario, pudiendo extinguir el contrato laboral con amparo en las causas previstas por la legalidad ordinaria, entre ellas el despido por razones objetivas (STC 146/19, de 25 de noviembre).

La doctrina, en este sentido, ha manifestado, por una parte, que «con esta previsión se ha llegado a hablar de una prohibición de despedir que, sin embargo, no se ajusta al tenor de la norma, que solo declara la extinción del contrato carente de causa, con la finalidad de que las empresas realicen los ajustes de empleo a través de los ERTE. No obstante, lo que sí se plantea es la problemática de la calificación jurídica que merezca un despido o una extinción de un contrato de trabajo que se consecuencia de la fuerza mayor o de las causas económicas, técnicas, organizativas y producción COVID-19» (González, 2020; 339).

Por otra,

afirmar que un despido se encuentra "prohibido" tiene una escasa precisión técnica desde el punto de vista jurídico, pues lo prohibido a lo más puede interpretarse como sinónimo de conducta «ilícita», cuando el jurista espera concreción de cuáles son las concretas consecuencias de ese ilícito, que por ampliar el abanico va desde el ilícito contractual hasta el ilícito penal, pasando por el ilícito administrativo. (Cruz, 2021)

Por último, descartar la existencia de una prohibición

es, en rigor, una limitación en la justificación de la causalidad de las extinciones, consistente en que aquellas causas que podían justificar medidas de flexibilidad interna no podrán justificar medidas de flexibilidad externa, esto es, la procedencia de los despidos — colectivos o individuales — por las mismas causas. (Agustí, 2020)

Por consiguiente, deja en manos del orden judicial determinar cuál es la calificación que merece un despido fundado en causas COVID-19: la nulidad o la improcedencia. Por ello, se ha señalado que «si el propósito del legislador era «jugar» con la ambigüedad, "delegando» en los tribunales la concreción de esta cuestión, no me parece una estrategia acertada. (...) El sistema normativo no necesita más estresores y tampoco (...) [conviene] generar expectativas con estas dosis de incertidumbre» (Beltrán de Heredia, 2020).

Para dilucidar todas estas dudas se pasarán a estudiar las sentencias más relevantes habidas, hasta el momento. Se adelanta que las interpretaciones que han dado los diferentes órganos judiciales, en cuanto al ámbito de aplicación, han

18 Vid. SSTC 88/1985, de 19 de julio y 89/2018, de 12 de octubre. 
sido variadas: extensiva [Interpretación más amplia o extensa de todos los sentidos posibles, pese a ser muy imprecisa (Rodríguez-T3oubes, 2019); es decir, supone un ámbito de aplicación del precepto mayor que el que se deriva de entender las palabras siguiendo el uso común del lenguaje], restrictiva-extensiva (la unión de los dos tipos de interpretaciones), restrictiva (Interpretación que le da al precepto un ámbito de aplicación menor que el que surge de entender las palabras del mismo según lo que sería el uso común del lenguaje) o no se aplica al despido disciplinario. Empero, se avanza que la inseguridad jurídica existente de la norma se solventará con la doctrina del Tribunal Supremo.

Por ejemplo, se ha indicado, como interpretación extensiva, que

concurre, además, otra causa de improcedencia basada en lo dispuesto en el art. 2 del Real Decreto Ley 9/2020, de 27 de marzo, de medidas complementarias, en el ámbito laboral para paliar los efectos derivados del COVID-19, precepto que imposibilitaba los despidos basados en causas objetivas durante la vigencia del estado de alarma derivado de la situación sanitaria. (SJS núm. 1 de Ponferrada, de 9 de octubre de 2020. Rec. núm. 225/20)

\section{Asimismo, que}

la norma prohibitiva es de aplicación a todas las empresas, hayan estado o no en situación de regulación de empleo. Cualquier empresa queda dentro del ámbito de aplicación de la norma excepcional y no debe despedir o extinguir los contratos por causa de fuerza mayor o por causas objetivas relacionadas con la COVID-19 (en este mismo sentido el criterio interpretativo de la Dirección general de Trabajo para la DGT-SGON-863CRA). (SJS de Pamplona, núm. 3, de 21 de diciembre de 2020. Rec. núm. 637/20)

Bajo este contexto, se ha señalado, como interpretación restrictiva-extensiva, que

a la vista de la literalidad del artículo 22 del RDL 8/2020, pensamos que no es aplicable el artículo 2 del RDL 9/2020 y por tanto hemos de acudir a la legislación ordinaria. En efecto, el citado artículo 22 establece que la legislación de urgencia será aplicable a aquellos supuestos que «tengan su causa directa en pérdidas de actividad como consecuencia del COVID-19» (...): ello, a nuestro modo de ver, implica que dicha normativa no es aplicable en los supuestos en que la COVID-19 no se configure como la causa directa o, dicho en otras palabras, se configure como una causa indirecta o mediata. Ciertamente la decisión legislativa podría haber sido otra (cuya validez constitucional no debemos ni plantearnos, al ser una mera especulación) pero lo cierto es que la norma en vigor establece con total claridad su incidencia, su ámbito de regulación, únicamente para los supuestos de necesidad de adopción de acuerdos de flexibilidad, sea interna (artículos 22 y 23 RDL 8/2020) o externa (artículo 2 RDL 9/2020), originados por perdida de actividad por causa directa de la COVID-19. Y es evidente que la literalidad de la expresión permite pocas dudas in- 
terpretativas, tal como nos impone el artículo 3 del Código Civil. (STSJ de Cataluña, de 11 de diciembre de 2020. Rec. núm. 66/20) ${ }^{19}$

\section{Como interpretación restrictiva se ha indica que}

para el caso que la empresa haya decidido acogerse a estas medidas extraordinarias que suponen un E.R.T.E. bien de suspensión, bien de reducción de jornada por causa de fuerza mayor o por causa económica, técnica, organizativa y de producción cuyo origen sea la Covid-19, que tales causas no podrán ser invocadas por la empresa para proceder al despido objetivo por causas económicas de sus trabajadores. (SJS de Valencia, núm. 14, de 1 de febrero de 2021. Rec. núm. 37/21) 20

Con relación a la salvaguarda del empleo, hay que indicar que de conformidad con la Disposición adicional sexta del RDL 8/2020, que se le ha tachado un tanto parca y escueta su redacción (Navarro y Alonso, 2021; 157), las medidas extraordinarias en el ámbito laboral previstas en el aludido artículo 22 están sujetas al compromiso de la empresa de mantener el empleo durante el plazo de seis meses desde la fecha de reanudación de la actividad, en el que el legislador indica que se entiende por tal la reincorporación al trabajo efectivo de personas afectadas por el expediente, aun cuando esta sea parcial o solo afecte a parte de la plantilla.

Bajo este contexto, en un supuesto de despido colectivo, no acordado con la representación legal de los trabajadores, que afecta a toda la plantilla de un hotel, con posterioridad a un ERTE suspensivo, siguiendo el razonamiento de la STSJ de la Comunidad Valenciana, de 1 de diciembre 2020 (rec. 24/2020), se ha manifestado que,

el riesgo de concurso exime del compromiso de mantenimiento del empleo, es calificado como procedente aunque la empresa tuvo ganancias en el ańo anterior, por las siguientes razones: Por una parte, concurren las causas económicas y producti-

19 En el mismo sentido, la STSJ de Madrid 30 de noviembre 2020. Rec. 399/2020 al indicar que en «primer lugar hemos de señalar que no son de aplicación el artículo 2 y la disposición final

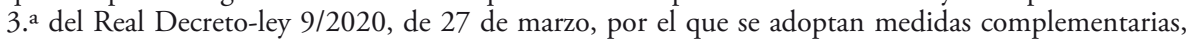
en el ámbito laboral, para paliar los efectos derivados del COVID-19, que solo afectan a aquellas situaciones que tengan su causa directa en pérdidas de actividad como consecuencia del covid19, lo que aquí no acontece, al alegarse causas estructurales, por lo que el despido colectivo es el procedimiento adecuado a los fines de extinguir las relaciones laborales por causas económicas anteriores al estado de alarma, sentando el Tribunal Supremo en la jurisprudencia expuesta, que los ERE deben tener génesis en causas estructurales y los ERTE han de hallarla en las coyunturales (...) nos encontramos con el supuesto contemplado en el artículo 51.1 del Estatuto de los Trabajadores, de pérdidas persistentes, que justifican el despido colectivo por causas económicas, habiéndose probado su existencia y, conforme a la doctrina jurisprudencial, constatada la falta de viabilidad de la empresa y la extinción de la sociedad en concurso de acreedores, la medida de despido de todos los trabajadores es razonable y proporcionada».

20 Entre otras, SJS de Valencia, núm. 14, de 1 de febrero 2021. Rec. núm. 37/2021. 
vas provocadas por el COVID-19. Por otra, no aplica el compromiso de empleo ex Disposición Adicional 6. ${ }^{\mathrm{a}}$ del RDL 8/2020 porque se ha concluido el concurso de acreedores. Por último, sin aplicar el artículo 2 del RDL 9/2020 «no cabe sino concluir que el despido impugnado es ajustado a derecho al haberse acreditado tanto las causas económicas como productivas alegadas y haber sido declarada la empresa en concurso de acreedores con simultánea conclusión del mismo por insuficiencia de la masa.

\section{Bajo este contexto, en}

el despido de la trabajadora, no puede enmarcarse, en el RD 9/2020, en cuyo art. 2, por cuanto la propia normativa exige que las extinciones tengan su causa directa en pérdidas de actividad como consecuencia del COVID-19, incluida la declaración del estado de alarma, y la causa del despido objeto de las presentes actuaciones, no deriva de la declaración del Estado de Alarma, ni trae causa directa ni indirecta de la COVID-19, no viene precedido de una suspensión de contrato ni reducción de jornada, ni trae causa en la situación sanitaria provocada por la COVID-19, sino en la pérdida del cliente principal de la empresa demandada (SJS núm. 3 de León, de 9 de octubre de 2020 (Rec. núm. 366/20).

Finalmente, que el artículo 2 RDL 9/2020 no es aplicable al caso porque la empresa no ha acudido a un ERTE de las características citadas (SJS de Salamanca, núm. 2, de 21 de octubre de 2020. Rec. núm. 444/20).

\section{De igual manera,}

la norma prevista en el artículo 2 del Real Decreto-ley 9/2020, de 27 de marzo, no es aplicable a este caso porque, como dicen los demandados, si bien es cierto que la reducción operada unilateralmente por FMPB en el contrato suscrito con la empresa demandada deriva directamente de los efectos de la pandemia y el estado de alarma sobre la afluencia de visitantes al museo (...) entregado a la representación de los trabajadores en el periodo de consultas, la reducción se lleva a cabo con carácter definitivo, como se deduce de la modificación operada en el contrato con motivo del levantamiento de la suspensión del mismo (...), en la que no hay ninguna referencia a la temporalidad de la reducción, lo que obliga a la empresa demandada a ajustar su plantilla, igualmente con carácter definitivo, esto es, mediante el despido colectivo con invocación de causa de producción, al amparo de la causa prevista en el artículo 51.1 ET. No nos encontramos, por tanto, ante la situación coyuntural que justifica la regulación prevista en los artículos 22 y 23 del Real Decreto-ley 8/2020, de 17 de marzo, por lo que no tiene sentido alguno aplicar la norma prevista en el artículo 2 del Real Decreto-ley 9/2020, de 27 de marzo. Por otra parte, el hecho de que la disminución de visitantes al museo pueda no ser irreversible, cosa que se plantea en el informe emitido por la gerente de FMPB (...), donde refiere la disminución de visitantes al medio plazo, no es relevante, dado que, con independencia de ello, el cliente decide reducir el contrato con carácter definitivo, decisión que la empresa demandada, en su calidad de contratista, se ve obligada a asumir, de modo que la posible temporalidad de la pérdida, ligada a los efectos de la pandemia, no puede producir efecto alguno en la empresa demandada. (STSJ de Cataluña, de 24 de noviembre de 2020. Rec. 56/2020) 


\section{Por tanto, el precepto en cuestión debe de interpretarse}

en el sentido de que no puede referirse sino al periodo durante el cual estén vigentes las medidas que justifican la fuerza mayor o las causas económicas, técnicas, organizativas o de producción. (STSJ de Aragón, de 15 de febrero 2021. Rec. 679/2020)

La STSJ de Aragón 15 de febrero 2021 (Rec. 38/2021), en este sentido, hace recordar la sentencia del Alto Tribunal que dispone que

el empresario es el que debe decidir soberanamente si procede acudir a medidas extintivas [ERE] o meramente suspensivas [ERTE]; y aunque una racional interpretación sistemática de ambos preceptos induce a concluir que en principio los ERE deben tener génesis en causas estructurales y los ERTE han de hallarla en las coyunturales, en todo caso resulta claro que corresponde a la exclusiva gestión empresarial decidir si está en presencia de una situación meramente coyuntural o si para ella ya es estructural, de forma tal que el acudir a un ERE o a un ERTE viene a traducirse en un juicio de «oportunidad» que exclusivamente corresponde a la dirección de la empresa. Ello con la obligada exclusión de los supuestos de abuso del derecho o fraude de ley, que lógicamente no pueden encontrar amparo en una decisión que se presenta antijurídica; en el bien entendido de que esas excepciones han de ser objeto del correspondiente alegato y de cumplida prueba. (STS de 17 de julio de 2014. Rec. 32/2014)

Sin embargo, en el supuesto en el que una empresa cesionaria no asume a un trabajador tras un traspaso, se ha señalado que - solo se aplica el artículo 2 del RDL 9/2020 — si se ha producido un despido fundamentado en causas objetivas (SJS Gijón, núm. 1, de 4 de diciembre 2020. Rec. 408/2020).

Con relación a que no se aplica al despido disciplinario, se ha indicado que

el artículo $29 / 2020$ no permite la extinción por causas objetivas del contrato, siendo así que nos hallamos ante un despido disciplinario, por lo que, en principio, no resultaría de aplicación. De entender que se ha calificado como disciplinario para orillar otras figuras extintivas, tendría que haber un indicio de que, por el contrario, respondía a circunstancias vinculadas a factores económicos, de producción u organizativos (consecuencia o no de la pandemia). Circunstancia que no concurre y que, en el caso de autos resulta poco plausible. (SJS núm. 3 de Gijón, de 18 de septiembre de 2020. Rec. núm. 277/20)

Asimismo, se ha entendido que aquel precepto no es aplicable al despido disciplinario, puesto que

del articulado del Convenio 158 de la OIT no cabe deducir que la consecuencia derivada de un despido sin causa haya de ser necesariamente la declaración de nulidad del mismo y la consiguiente readmisión del trabajador. El propio Convenio permite, como alternativa a la anulación de la decisión extintiva, la compensación del trabajador mediante el pago de una indemnización adecuada u otra reparación que se considere apropiada. (STSJ de Asturias, 26 de enero 2021. Rec. 1945/2020) 
En cuanto a los efectos del incumplimiento del artículo 2 del RDL 9/2020, el órgano judicial ha aplicado diferentes soluciones: nulidad, improcedencia más indemnización complementaria - o la unión de las anteriores- o procedencia. Bajo este contexto, se ha señalado que la calificación debe ser, por una parte, la nulidad, incluso en un supuesto extintivo anterior a la entrada en vigor del RDL 9/2020 (SJS núm. 3 de Sabadell, de 6 de julio de 2020. Rec. núm. 93/20). Por otra, la nulidad de pleno derecho conforme el artículo 6.3 del Código Civil (SJS de Barcelona, núm. 99, de 28 de julio de 2020. Rec. núm. 180/20 y SJS de Oviedo, núm. 6, de 22 de octubre de 2020. Rec. núm. 305/20).

Con relación a la primera sentencia de las nombradas merece la pena destacar que aquella indica que

en la carta de extinción de contrato se hace referencia a la finalización de la obra o servicio para el que fue contratada, cuando lo cierto es que, de estimar los argumentos de la empresa, esto es, de considerar que estábamos ante un contrato temporal, debió adoptar las medidas previstas en RDL 8/2020 y en su caso suspender el cómputo de vigencia del contrato de trabajo en aplicación de artículo 5 RD 9/2020, ya que, según se reconoció en acto de juicio, en realidad se extinguió el contrato de trabajo a cinco de los empleados como consecuencia de la disminución de pedidos y de producción derivada de la declaración del Estado de Alarma.

En definitiva, se considera que, en realidad, la extinción de contrato de la actora se produjo como consecuencia de la situación derivada de la declaración del Estado de Alarma y la existencia de circunstancias que habilitaban a la empresa para adoptar las medidas previstas en $\mathrm{RD} 8 / 2020$ por lo que, al extinguir la relación laboral de la actora no solo aduce una causa que no justifica la extinción, según los artículos 22 y 23 de RDL 8/2020 y artículo 2 - de RDL 9/2020-, sino que supone un incumplimiento de las disposiciones legales adoptadas por el legislador con la finalidad de evitar la destrucción de empleo, finalidad que se refleja en Exposición de Motivos (III) del RD 8/20, en que sostiene que las medidas del Cap III del RD-Ley 8/2020 están orientadas a evitar despidos y a conservar el empleo, y esa finalidad habrá de predominar en la hermenéutica que regula los despido en el ámbito excepcional del COVID-19, siendo esta finalidad la que justifica la redacción del artículo 2 RDLey $9 / 2020$.

Siendo así, consideramos de aplicación el artículo 6.3 — de Código Civilpor cuanto la extinción del contrato de trabajo de la actora constituye un acto contrario a norma imperativa además de constituir un fraude de ley, artículo 6.4 - de Código Civil—, pues la empresa se ampara en causa inexistente para conseguir un resultado prohibido por el ordenamiento jurídico, esto es, la extinción de la relación laboral a fecha 28.3.2020, cuando las normas vigentes proscriben la destrucción de empleo derivada de la situación excepcional del Estado de alarma derivado de COVID-19. En consecuencia, procede declarar la nulidad del despido notificado a la actora con efectos de 28.3.2020, con las consecuencias previstas en artículo 55.6 TRLET. 
La doctrina, con relación al artículo 6 del Código Civil, ha señalado, por una parte, que

el instrumento de la nulidad (en aquel precepto) está programado, esencialmente, para expurgar aquellos actos y negocios jurídicos contrarios a normas imperativas, propiciando normalmente un efecto inverso (anulación del contrato) al que converge el predicado de nulidad del acto extintivo laboral. Por lo anterior, no son despreciables los problemas que debiera ocasionar la exportación acrítica de una figura como la que aquí estudiamos, cuando el cometido que se le pretende encomendar en el ordenamiento receptor circula en sentido contrario (conservación del negocio jurídico) a aquel para el que ha sido esencialmente concebida (anulación del negocio jurídico). (...) la proyección de la nulidad civil ex art. 6.3 CC al ámbito de la relación obligatoria laboral no puede hacerse a costa de despojarle del carácter que le atribuye la propia doctrina de la Sala 1..$^{\text {a }}$ del TS, cuando la toma como un remedio excepcional para expurgar aquellos actos y negocios jurídicos que afecten de forma sustancial al orden público, con la habitual intención de anularlos y no de mantenerlos vivos. (Segalés, 2021;37)

\section{Por otra,}

en caso de fraude procede la aplicación de la norma que se hubiera tratado de eludir (que, para el despido, implica la declaración de improcedencia al no estar justificada la extinción) en caso de abuso de derecho, procede el abono de la correspondiente indemnización (objetivo que también queda cubierto con la declaración de improcedencia) y la nulidad prevista en el art. 6.3 solo opera para los casos en los que la norma imperativa o prohibitiva vulnerada no haya previsto un efecto distinto para el caso de contravención (tarea que, con respecto al contrato de trabajo, asume el ET). (Viqueira, 2020)

En cuanto a la interpretación de improcedencia más una indemnización complementaria se destaca aquella que señala que la indemnización legal tasada no es "suficientemente disuasoria" y, por ello, reconoce una indemnización complementaria de $60.000 €$ a compensar con la ya percibida, salvo readmisión (SJS núm. 26 de Barcelona, de 31 de julio de 2020. Rec. núm. 170/20). Así como el reconocimiento de indemnización de casi $49.000 €$, por 9 meses de salario), salvo readmisión (SJS de Barcelona, núm. 26, de 31 de julio de 2020. Rec. núm. 174/20).

Por ejemplo, en un supuesto de despido improcedente habiéndose declarado el estado de alarma, antes de la entrada en vigor del RDL 8/2020 y RDL 9/2020, se ha indicado que

no nos encontramos en estos supuestos ante un despido prohibido sino injustificado ("no se podrán entender como justificativas» las causas COVID-19 señala el precepto Y con ello ante un despido improcedente. Ni siquiera la vía de despido por fraude de ley permitirá la declaración de nulidad, que no admite como tal la jurispruden- 
cia, salvo para determinados supuestos de despidos colectivos fraudulentos (STS de 5 de mayo de 2015, rec. 2659/2013), pero más por la vinculación con la vulneración del derecho a la negociación colectiva y a la libertad sindical por las graves irregularidades o incumplimientos de los deberes documentales e informativos que impone a la empresa la normativa aplicable. (STSJ de Castilla y León, de 15 de enero 2021. Rec. 429/2020)

\section{Asimismo,}

el artículo 2 del RDL 9/2020, pudiendo haber calificado al despido como nulo, ha optado por no hacerlo. Nada dispone tampoco sobre la calificación, la Exposición de motivos del propio RDL. (...) En ningún momento se anuncia en la norma, como una medida a adoptar, en aras a evitar que las causas del artículo 22 del RDL 8/2020 se traduzcan en un despido, su calificación de nulidad. No se prevé en el RDL 9/2020 de este modo, una prohibición de despido bajo sanción de nulidad por lo que, siendo un principio general de derecho el que afirma que donde la norma no distingue no debe distinguir el intérprete (SSTS 12-7-18, Rec. n. ${ }^{\circ}$ 182/17 y 13-06-2018, Rec. n. ${ }^{\circ}$ 128/2017), sobre todo, porque tampoco se ha modificado y bien podía haberlo hecho, la redacción del artículo 124 de la LRJS, el despido no puede calificarse como nulo. (...) si la norma en cuestión, detallada y densa en su contenido, nada prevé, no es razonable interpretar ese silencio como un mero olvido. (STSJ Madrid, de 25 de noviembre 2020. Rec. 590/2020)

\section{En el mismo sentido,}

el art. 2 del Real Decreto Ley 9/2020 no introduce una prohibición, sino que solo se limita a apuntar que las causas de fuerza mayor o de carácter económico, técnico, organizativo o productivo, derivadas de la crisis por el Covid 19, que podrían justificar un expediente de regulación temporal de empleo, con la mera previsión de que estas causas no justifican el despido, un despido sin causa es improcedente; pero no nulo. (SJS de Ciudad Real, núm. 1, de 10 de diciembre 2020. Rec. 414/2020)21

La jurisprudencia mayoritaria se ha decantado por la improcedencia ${ }^{22}$. Por ejemplo, se ha manifestado que

21 En términos similares, SJS de Ciudad Real, núm. 3, de 30 de noviembre 2020. Rec.418/2020.

22 Se destacan, entre otras y en el mismo sentido, las siguientes: SJS de Palencia, núm. 1, de 1 de octubre de 2020. Rec. núm. 281/20; SJS de Ciudad Real, núm. 3, de 29 de septiembre de 2020. Rec. núm. 234/20; SJS de Salamanca, núm. 2, de 21 de octubre de 2020. Rec. núm. 444/20; SJS de Valladolid, núm. 4, de 14 de octubre de 2020. Rec. núm. 335/20; SSJS de León, núm. 1, de 1 de octubre de 2020. Rec. núm. 253/20 y 22 de septiembre de 2020. Rec. núm. 261/20 y Rec. núm. 331/20; SJS de Soria, núm. 1, de 9 de septiembre de 2020. Rec. núm. 216/20; SSJS de Gijón, núm. 3, de 3 de noviembre de 2020. Rec. núm. 316/20 y 18 de septiembre de 2020 . Rec. núm. 277/20; SJS de Oviedo, núm. 1, de 19 de octubre de 2020. Rec. núm. 295/20; SJS de Mieres, núm. 1, de 4 de agosto de 2020. Rec. núm. 319/20; SJS de Barcelona, núm. 35, de 18 de noviembre de 2020. Rec. núm. 50/20; SSJS de Barcelona, núm. 26, de 13 de octubre de 2020. Rec. núm. 229/20 y 31 de julio de 2020. Rec. núm. 168/20; SSJS de Valladolid, núm. 5 , 
el artículo 2 del RDL 9/2020, pudiendo haber calificado al despido como nulo, ha optado por no hacerlo. Nada dispone tampoco sobre la calificación, la Exposición de motivos del propio RDL. No se prevé en el RDL 9/2020 (...) una prohibición de despido bajo sanción de nulidad por lo que, siendo un principio general de derecho el que afirma que donde la norma no distingue no debe distinguir el intérprete (...), sobre todo, porque tampoco se ha modificado y bien podía haberlo hecho, la redacción del artículo 124 de la LRJS, el despido no puede calificarse como nulo. (...) $[\mathrm{No}$ ] es razonable interpretar ese silencio como un mero olvido (...) La palabra «justificativa» significa que «sirve para justificar algo» y el verbo «justificar» significa (...) «probar algo con razones convincentes, testigos o documentos». Por ello, si la causa productiva, no es justificativa del despido, esto significa que la causa productiva relacionada con el Covid-19 no lo prueba, el despido no está probado y, por lo tanto, resulta improcedente o en este caso, no ajustado a derecho. No nulo.

\section{De igual manera,}

no prohíbe los despidos, sino que tan solo establece que la FM, o las causas ETOP utilizadas para los ERTES «...no se podrán entender como justificativas de la extinción $\mathrm{dl}$ contrato de trabajo ni del despido...»; en consecuencia, se exige que se haya seguido con anterioridad un ERTE y, dichos ceses, fundados en las mismas causas, serían despidos sin justificación, es decir, despidos sin causa, y, por tanto, improcedente (convenio 158 OIT). En todo caso, es preciso recordar que no cabe interpretar que toda conducta empresarial de dejar sin efecto un compromiso de empleo comporta ineludiblemente la concurrencia de un fraude de ley y, por tanto, de declaración de nulidad del despido colectivo. (SJS León, núm. 1, de octubre 2020. Rec. 253/2020) 23

\section{Por consiguiente,}

la invocación de fuerza mayor o causas económicas, técnicas, organizativas y de producción, estando vigente el art. 2 del Real Decreto Ley 9/2020, no constituye causa justificativa de la extinción. Y en este punto no cabe más que aplicar la consolidada jurisprudencia del Tribunal Supremo en materia de despido sin causa, reflejada en sentencias como la de 05/05/15 (ECLI:ES:TS:2015:2469), relativa además al despido de un trabajador en IT, que declara: «Esta línea jurisprudencial sobre la carencia de «apoyo o refrendo legal» de la nulidad del despido fraudulento se inicia en STS 2-11-1993 (rec. 3669/1992), a la que corresponden los párrafos en-

de 21 de julio de 2020. Rec. núm. 237/20 y 14 de octubre de 2020. Rec. núm. 335/20; SSJS de Palma de Mallorca, núm. 4, de 31 de agosto de 2020. Rec. núm. 304/2020 y 5 de julio de 2020. Rec. núm. 346/20, SJS de Bilbao, núm. 11, de 19 de noviembre de 2020. Rec. núm. 6/20; SSJS núm. 1 de Ponferrada, de 9 de octubre de 2020. Rec. núm. 225/20 y 24 de junio de 2020. Rec. núm. 174/20; SJS de Toledo, núm. 2, de 18 de noviembre 2020. Rec. 959/2020; SJS de Arrecife, núm. 3, de 24 de marzo 2021. Rec. 325/2020; SJS de Palencia, núm. 1, de 29 de octubre 2020. Rec. 274/2020; y, SJS de Palencia, núm. 1, de 1 de diciembre 2020. Rec. 269/2020.

23 En términos similares, SSJS León, núm. 2, de 22 de septiembre 2020 (Rec. 261/2020 y Rec. 331/2020). 
trecomillados, y continúa en STS 19-1-1994 (rec. 3400/1992), STS 23-5-1996 (rec. 2369/1995) y 30-12-1997 (rec. 1649/1997). "Cuando no hay causa legal para la extinción del contrato de trabajo y la causa real no se encuentra entre las tipificadas como determinantes de la nulidad del despido - concluye STS 29-2-2001 (citada) - la calificación aplicable es la de improcedencia» del despido, y no la de nulidad del mismo". A la vista de lo anterior, debe calificarse la decisión extintiva como improcedente. (SJS de Soria, núm. 1, de 9 de septiembre 2020. Rec. 216/2020)

\section{En el mismo sentido, se ha dispuesto que}

nuestro ordenamiento jurídico (...), no consagra la categoría del despido nulo por falta de causa, sino que la calificación que se impone es la de la improcedencia del despido (arts. 55 del ET y 108 y 122 de la LRJS). (...) cuando no hay causa legal para la extinción del contrato (...) la calificación aplicable es la de la improcedencia del despido y no la de nulidad del mismo. Por lo tanto, no nos encontramos (...) ante un despido prohibido sino injustificado (...) y con ello ante un despido improcedente. Ni siquiera la vía de despido por fraude de ley permitirá la declaración de nulidad, que no admite como tal la jurisprudencia, salvo para determinados supuestos de despidos colectivos fraudulentos. (...) la utilización del vocablo «justificativas», unida a la inexistencia de la más mínima referencia a la nulidad de la medida, conduce a interpretar que la fuerza mayor y las causas económicas, técnicas, organizativas o productivas vinculadas a la Covid-19, no acreditan las extinciones contractuales. El legislador ha situado el debate en el plano procesal de los efectos del despido, conduciendo la conclusión que se obtiene a la declaración de improcedencia y quedando descartada la nulidad. (SJS de Pamplona, núm. 3, de 21 de diciembre de 2020. Rec. núm. 637/20)

\section{Asimismo, se ha señalado que}

lo cierto es que el legislador ha tenido en sus manos la posibilidad de dar una respuesta clara a la cuestión litigiosa y, sin embargo, ha preferido publicar una norma de contenido impreciso (...) no cabe sino considerar que estamos ante una voluntad legislativa favorable a la declaración de la improcedencia y no a la de la nulidad de la extinción o despido de que se trata (...) La declaración de la improcedencia no implica acoger como causa válida de extinción de la relación laboral el desistimiento empresarial, lo que prohíbe el Convenio 158 de la OIT. Todo lo contrario, implica negar que la simple voluntad de la empleadora justifique el despido. Pero ni el régimen general del fraude de ley ni el del abuso del derecho, recogidos en los arts. 6.4 y 7.2 del Código Civil, respectivamente, imponen la declaración de nulidad del acto jurídico de que se trata. (SJS de Pamplona, núm. 3, de 21 de diciembre de 2020. Rec. núm. 637/20)

\section{Bajo este contexto,}

no existe vulneración del artículo 24 de la CE, sino, como se ha dicho, un despido sin expresión de la causa, que no ha impedido al trabajador ejercitar su derecho ante la jurisdicción social. Por último, las normas invocadas y dictadas durante el 
estado de alarma prevén la falta de justificación del despido objetivo en las especiales circunstancias concurrentes, pero no regula las consecuencias de la vulneración de dicha prohibición, ni expresa que en ese caso concurra la nulidad del despido, ni implica modificación alguna respecto a la previsión legal existente en la materia en la Ley Reguladora de la Jurisdicción Social, por lo que, por lo que respecta a los supuestos de nulidad del despido por causas objetivas, continúan siendo de aplicación las causas previstas en el art. 122.2 LJS, sin que se den, en este supuesto, ninguno de los casos expresamente previstos en la norma. En suma, estamos ante un despido tácito, sin comunicación escrita ni expresión de la causa, en el contexto del estado de alarma, sin duda contrario a derecho, pero cuya consecuencia legal es la declaración de improcedencia. (SJS de Palencia, núm. 1, de 1 de octubre 2020. Rec. 281/2020)

De igual manera, se ha indicado que «estamos, evidente es, aunque se le haya dado apariencia de despido disciplinario, ante un despido sin causa. La empresa ni siquiera ha tratado de acreditar la supuesta infracción del trabajador, no desplegando medio de prueba alguno con este objetivo, reconociendo en el juicio, como no podía ser de otra manera, la improcedencia.

El despido se produce en plena crisis sanitaria, y también económica, por la paralización de la actividad productiva, provocada por la pandemia de COVID-19, que justificó la declaración del estado de alarma. Estando ya vigente el art. 2 del Real Decreto Ley 9/2020, de 27 de marzo, que dispone:

la fuerza mayor y las causas económicas, técnicas, organizativas y de producción en las que se amparan las medidas de suspensión de contratos y reducción de jornada previstas en los artículos 22 y 23 del Real Decreto-ley 8/2020, de 17 de marzo, no se podrán entender como justificativas de la extinción del contrato de trabajo ni del despido.

Este juzgador considera, en tanto en cuanto no exista doctrina jurisprudencial unificada, que los despidos que tengan lugar contrariando el art. 2 del Real Decreto Ley 9/2020 deben ser declarados improcedentes, y no nulos, por las siguientes razones:

1. Por no existir obstáculo que permita predicar la aplicación de la doctrina jurisprudencial consolidada sobre los despidos sin causa.

2. ${ }^{\circ}$ Porque la declaración de nulidad debería reservarse para los casos más graves, expresamente previstos en la ley, especialmente relacionados con los derechos fundamentales.

3. ${ }^{\circ}$ Porque el art. 2 del Real Decreto Ley 9/2020 no introduce una prohibición. Se limita a apuntar que las causas de fuerza mayor o de carácter económico, técnico, organizativo o productivo, derivadas de la crisis por el COVID-19, que podrían justificar un expediente de regulación temporal de empleo (ERTE) de los previstos en el Real Decreto Ley 8/2020 
«no se podrán entender como justificativas de la extinción del contrato de trabajo ni del despido «. Y un despido sin causa es improcedente; pero no nulo» (SJS núm. 26 de Barcelona, de 10 de julio de 2020 (Rec. núm. 348/20).

\section{Finalmente, se ha dispuesto que el}

engarce entre el mantenimiento del empleo y la resolución irregular del contrato de trabajo por un acto unilateral del empresario nos conduce a la restitución ad integrum del vínculo laboral. Y ello por estas razones: primera, por la indisponibilidad de la norma excepcional por parte de cualquiera de los sujetos participantes en las relaciones laborales, tanto en la esfera de la voluntad general como en la particular de un contrato de trabajo (empresa y sindicatos), en cuanto que el tercer sujeto de las relaciones laborales, el público, es el que se ha atribuido las funciones de delimitar los parámetros funcionales y de reacción ante la pandemia y sus consecuencias; la segunda, porque solamente se acomoda a esa previsión de mantener el empleo y la situación previa a la generada con el RD 463/20, la reposición de la situación previa del trabajador al acto ilícito de su despido; tercera, porque la vis atractiva de la imposición a los empresarios y trabajadores de un sistema concreto de atender la crisis les ha privado de la disponibilidad de la extinción de los contratos de trabajo, y les obliga a asumir un instrumento concreto fuera del cual, en los supuestos del art. 22 RDL 8/2020 ( completado por el 2 del RDL 9/2020, para nuestro caso, y posteriormente el 30/2020), no hay alternativa: es ope legis. Fuera de los contornos legislativos no hay discrecionalidad; y, cuarto, porque esa no disposición de la facultad de despedir que establece el art. 2 del RDL 9/20 conduce a que no sea posible que por la declaración de despido improcedente se produzca lo que no ha querido la norma, y que a la postre se opte por la extinción del contrato mediante una indemnización, que es la posible consecuencia del despido improcedente. Si se admite ello se admitiría una quiebra de la misma norma, dejándola sin contenido eficaz.

No se trata de automatizar las instituciones propias del derecho laboral, sino de dotarles de su verdadero empaque. Por ello, no es que sea porque se trate de un posible despido fraudulento el que la consecuencia del mismo sea la nulidad, no, de lo que se trata es de que la voluntad de las partes ha quedado criogelizada, y se ha asumido por el legislador una función propia de los interlocutores sociales, que es la negociación y la disponibilidad de determinadas instituciones, creando un marco de derecho necesario. De aquí el que haya adquirido la preservación del empleo en la concreta situación generada una significación mayor a aquella que se había pretendido para otros casos; y todo el bloque normativo dictado para la pandemia forma un conjunto holístico y sistémico, propio y autónomo, ajeno al paralelismo ordinario de las figuras del derecho laboral y su regulación. En definitiva, se ha diseñado un sistema para la situación, con la configuración de las causas y formas de actuar, ERTE, y se ha colocado la protección del empleo frente a la pandemia en un rango electivo similar al de la protección de los derechos fundamentales; en el mismo rango que los derechos que determinan la consecuencia de la nulidad del despido. (STSJ del País Vasco, de 23 de febrero 2021. Rec. 57/2021) $)^{24}$

${ }^{24}$ En términos similares, la STSJ del País Vasco, de 26 de enero 2021. Rec. 1583/2020. 


\section{Por consiguiente,}

la existencia de un importante debate doctrinal y judicial en torno a esta cuestión. La Sala entiende que, aunque el legislador no haya determinado la calificación que han de merecer estos despidos que vulneran el artículo 2 del RDL 9/2020, nuestra consideración de tratarse de despidos en fraude de ley, vinculada a la necesaria efectividad del derecho al trabajo del artículo $35 \mathrm{CE}$ - en el que se inserta el derecho a no ser despedido sin justa causa - y a la clara voluntad legislativa de impedir los despidos por causas económicas, técnicas, organizativas y productivas en esta crisis derivada de la COVID-19, nos llevan a declarar la nulidad del despido. (SJS de Bilbao, núm. 6, de 6 de octubre 2020, núm. 183/2020)

En cuanto al despido declarado procedente, hay sentencias que señalan, por una parte, que el despido objetivo que es comunicado antes de la promulgación del RDL 9/2020, pero efectivo una vez vigente, es procedente si las causas económicas son anteriores a la pandemia (SJS de Gijón, núm. 4, de 25 de noviembre 2020. Rec. 223/2020) ${ }^{25}$.

\section{Por otra, que}

la empresa sí hizo uso de esas medidas, con un ERTE de fuerza mayor justificado por el descenso de actividad derivado del estado de alarma y el confinamiento inicial, y lo que plantea ya en verano de 2020 (ante la evidencia de la fuerza de la segunda ola) es una extinción en la que las causas principales son unas causas ETOP previas a la crisis sanitaria que esta última ha impedido remontar mínimamente. Todo lo razonado conduce a rechazar la improcedencia basada en la infracción del art. 2 RDL 9/2020. (SJS de Barcelona, núm. 31, de 5 de febrero 2021. Rec. núm. 59/2021)

Por último, se destaca una interesante sentencia que declara la procedencia del despido, en vista que el artículo 2 del RDL 9/2020 es contrario al derecho de la Unión Europea; al manifestar que

la normativa española, en tanto en cuanto establece una prohibición incondicionada a una tradicional medida de readaptación empresarial de amplio reconocimiento en todas las economías de la Unión Europea, y que todas las legislaciones someten a varios requisitos formales, materiales y de compensación en cuanto no es una causa imputable al trabajadores - no respeta esa legalidad comunitaria, de establecer un marco común de desarrollo social y económico, por lo que generando derecho subjetivos en los justificables merecen la protección y tutela de los órganos jurisdiccionales como tribunales de la Unión (entiende que la medida de aquel precepto vulnera el artículo 3.3 TFUE y el artículo $16 \mathrm{CEDF}$, por lo que) «procede su inaplicación (STJCEE 15/7/1964 Costa-Enel) en tanto en cuanto es merecedora de tutela el derecho de la demanda reconocido en los preceptos del TFUE y CEDF seńalados. (SJS de Barcelona, núm. 1, de 15 de diciembre 2020. Rec. núm. 283/2020)

25 De igual manera, se ha resuelto en SJS de Logroño, núm. 3, de 11 de diciembre 2020. Rec. 282/2020; y, SJS de Salamanca, núm. 2, de 30 de noviembre 2020. Rec. 558/2020. 


\section{Conclusiones}

El legislador ha intentado limitar los despidos masivos a consecuencia de la COVID-19, en el que ha tenido un gran protagonismo, entre otros, la promoción de los ERTES. Herramienta provisional que ha coadyuvado a paliar la situación de la crisis de las empresas, juntamente con una regulación de la prestación por desempleo extraordinaria. Empero, se ha señalado, en ese sentido,

lo refractarias que son las leyes sociolaborales de emergencia a formular técnicamente prohibiciones, pese a la difusa retórica político-gubernamental sobre su intención de dar esa dimensión a sus decisiones restrictivas de ceses laborales asociados al impacto de la covid19. (Molina, 2020; 91)

Queda claro, con todo lo analizado, que la redacción del artículo 2 del RDL 9/2020 presenta deficiencias para una correcta interpretación, que se le ha tachado de «difícil y controvertida exégesis» (Cabeza, 2020; 28), dado que contiene un régimen jurídico excesivamente incierto que puede a llegar a un colapso interpretativo; que culminará hasta que el Tribunal Supremo siente doctrina. En la aplicación de aquel precepto se juega con la contención del empleo y con la supervivencia de la empresa, así como en la estabilidad en el empleo de los que pierden y la estabilidad de aquellos que permanecen.

Aquellas medidas extraordinarias para la protección del empleo, como ya se ha comentado, han tenido varias prórrogas. La penúltima ha sido a través del artículo 1 del Real Decreto-ley 11/2021, de 27 de mayo, sobre medidas urgentes para la defensa del empleo, la reactivación económica y la protección de los trabajadores autónomos. Y la última a través del artículo 1 del Real Decretoley $18 / 2021$, de 28 de septiembre, de medidas urgentes para la protección del empleo, la recuperación económica y la mejora del mercado de trabajo, conocido como el VI Acuerdo Social en Defensa del Empleo, en el que se prorrogan los expedientes de regulación temporal de empleo vinculados a la crisis pandémica, siempre que cumplan con las exigencias impuestas, hasta el 28 de febrero de 2022.

En este sentido, se destaca que el reciente Real Decreto-ley 32/2021, de 28 de diciembre, de medidas urgentes para la reforma laboral, la garantía de la estabilidad en el empleo y la transformación del mercado de trabajo ${ }^{26}$, en la Disposición adicional tercera señala, de igual manera, que la tramitación y efectos de los expedientes de regulación temporal de empleo por impedimento o por limitaciones a la actividad normalizada vinculadas a la COVID-19, regulados en el artículo 2 del Real Decreto-ley 18/2021, de 28 de septiembre,

26 BOE núm. 313, de 30 de diciembre de 2021. 
seguirán rigiéndose por lo señalado en aquel precepto hasta el día 28 de febrero de 2022.

De todas esas prórrogas, ha quedado claro que, consisten en la reproducción de lo contenido en el artículo 2 del RDL 9/2020; por tanto, los problemas jurídicos seguirán siendo los mismos. Hubiese aprovechado el legislador, en esta ocasión, de aclarar la laguna existente (SJS de Pamplona, núm. 3, 21 de diciembre de 2020. Rec. 637/2020). Dicho de otra manera, hubiera colocado un poco de orden ante la extraordinaria confusión generada para no delegar la solución al orden judicial. Empero, se prevé que se está ante una voluntad legislativa favorable a la declaración de la improcedencia y no a la de la nulidad del despido a consecuencia de la pandemia.

Bajo este contexto, alguna sentencia ha seńalado que aquella normativa

nació (y así se deduce de la exposición de motivos del Real Decreto Ley 8/2020 y 9/2020) con una vocación de atender a una situación coyuntural de duración limitada, pero ya no puede calificarse así pues desde que comenzó a dictarse ha transcurrido casi [dos años] existiendo una gran incertidumbre en todo el planeta sobre cuál será su duración. En estas circunstancias, entiendo que no va a resultar fácil encontrar despidos que no estén 'relacionados' con la pandemia en los términos del artículo 2 del Real decreto ley 9/2020 en relación con el artículo 23 del Real decreto ley [8]/2020. Por lo que en todo caso habría que ser cautos en la interpretación de cuándo una decisión empresarial de poner fin a una relación laboral implica un fraude de ley, especialmente si a esa calificación le anudamos el deber de readmisión obligatoria como modo de rechazar la conducta empresarial fraudulenta. Entiendo que no puede generalizarse dicha conclusión a cualquier despido relacionado con la pandemia y habría que estar al caso concreto, sobre todo cuando pueda estar en peligro la supervivencia de la empresa y la estabilidad en el empleo de otros trabajadores, pues en definitiva hemos comenzado diciendo que es la finalidad de evitar la destrucción estructural del empleo la que debe dominar la interpretación que regula los despidos en el ámbito excepcional de esta normativa anti COVID. (STSJ País Vasco 23 de febrero 2021. Rec. 57/2021)

Hay que tener en cuenta, no obstante, que el artículo 2 del RDL 9/2020, por una parte, no distingue entre despidos con una afectación individual o despidos con afectación colectiva. Por otra, no hay que confundir aquella prohibición de despedir con los compromisos de mantenimiento de empleo durante seis meses para las empresas que se hayan acogido a las medidas extraordinarias en materia de cotización previstas en el RDL 8/2020.

Con relación a la libertad de empresa y con la naturaleza autónoma y diferenciada de los mecanismos de flexibilidad interna y externa, habría que realizar una interpretación sistemática de los artículos 51 y 47.1 del ET; al entender que, en principio, los ERE deben tener génesis en causas estructurales y los ERTE han de hallarla en las coyunturales. En este sentido, la sentencia del Tri- 
bunal Supremo de 9 de septiembre de 2020 (Rec. 13/2018) concluye que ante problemas estructurales no es posible acudir al ERTE. Por consiguiente, la interpretación que se le daría al artículo 2, que se comenta, es que

no estaría impidiendo llevar a cabo extinciones, incluso derivadas de la pandemia, cuando las mismas descansen en causas estructurales, sino que la prohibición se aplicaría únicamente a las extinciones basadas en razones coyunturales. (Aranaz, 2021)

En este sentido, se recuerda la STSJ de Aragón de 15 febrero de 2021 (Rec. 38/2021) que decreta la procedencia de un despido objetivo amparado en causas anteriores a la pandemia y respecto de las cuales la empresa no acudió a un ERTE, argumentando que no es obligatorio acudir a las medidas excepcionales a las que se refieren los artículos 22 y 23 del RDL 8/2020.

$\mathrm{Al}$ igual que el modelo italiano —el decreto ley «Cura Italia»— (Baylos, 2020), el legislador español se inspiró en aquel para colocar una limitación inicial en el artículo 2 del RDL 9/2020 al señalar, como ya se ha comentado, que las causas que dan lugar a los ERTES, tanto por fuerza mayor como por causas económicas, técnicas, organizativas y de producción, no pueden ser alegados por la empresa con el objeto de dar por finalizado el contrato de trabajo (Falguera, 2020; 110).

Si se mira a Latinoamérica, los legisladores tienen otra visión. En Argentina, por ejemplo, el Decreto de Necesidad y Urgencia (DNU) 329/2020 (BO 31/3/2020) prohíbe, explícitamente, los despidos y suspensiones «sin justa causa y por las causales de falta o disminución de trabajo y fuerza mayor por 60 días». La finalidad de la medida es la de "garantizar la conservación de los puestos de trabajo por un plazo razonable, en aras de preservar la paz social y que ello solo será posible si se transita la emergencia con un Diálogo Social en todos los niveles y no con medidas unilaterales» (Grosolía, 2021). El artículo 4 de aquella norma, con el afán de dejar claro la prohibición de despedir, establece claramente que

los despidos y las suspensiones que se dispongan en violación de lo dispuesto en el artículo $2 .^{\circ}$ y primer párrafo del artículo $3 .^{\circ}$ del presente decreto, no producirán efecto alguno, manteniéndose vigentes las relaciones laborales existentes y sus condiciones actuales.

Como puede observarse, la visión es muy diferente a la europea: se busca la estabilidad real absoluta.

La redacción dada por el legislador español no establece una prohibición de despedir, solo pretende articular todos los casos de limitación o reducción de actividad productiva por la vía de las suspensiones de contrato o la reducción de jornada. Por lo que no queda claro cuáles son los efectos del incumplimiento de dicho precepto sobre la calificación del despido. Resulta evidente, como ya se ha 
apuntado, que el legislador deja en manos del orden social la concreción de los efectos, con el objeto de que tenga la última palabra el Alto Tribunal.

Hubiese sido más fácil y sencillo si el legislador lo hubiera señalado de manera expresa, por ejemplo, al indicar

la fuerza mayor las causas ETOP en las que se amparan las medidas de suspensión de contratos y reducción de jornada previstas en los artículos 22 y 23 del RDL 8/2020... quedarán prohibidas como causas de extinción del contrato de trabajo ni del despido mientras estas estén en vigor. (Molina, 2020; 91)

Lo que ha quedado claro es que la postura mayoritaria seguida por los Juzgados de lo Social en la de considerar a los despidos, que tengan lugar contrariando el artículo 2 del RDL 9/2020, es que deben ser declarados improcedentes y no nulos; teniendo en cuenta las diversas consideraciones analizadas (Poquet, 2021).

La improcedencia de los despidos que infrinjan el señalado precepto se fundamenta, por una parte, en que la declaración de nulidad solo se debe reservar para los casos expresamente previstos en la ley; especialmente, relacionados con los derechos fundamentales conforme el artículo 55.5 del ET. Por otra, el aludido precepto no introduce una prohibición de despedir, sino que se limita a apuntar que las causas de fuerza mayor o de carácter económico, técnico, organizativo o productivo, derivadas de la crisis por la COVID-19, no pueden justificar un despido o una extinción del contrato. En todo caso, se produciría un despido sin causa, pero no se prohíbe el despido sin más. Por último, la no obstaculización normativa que permita mostrar la aplicación de la doctrina jurisprudencial consolidada sobre los despidos sin causa, que se califican como improcedentes.

Si el legislador no ha establecido expresamente la sanción de nulidad, tanto en la Exposición de motivos del RDL 9/2020, como en la misma norma y en las numerosas prórrogas que se han venido realizado de esta, permite afirmar que su verdadera voluntad fue someterla a las normas laborales vigentes y a la interpretación jurisprudencial de las mismas; la cual califica a los despidos sin causa como despidos improcedentes, no nulos (López, 2021).

Bajo este mismo criterio, una reciente sentencia se ha pronunciado al indicar que

la nulidad no aparece de forma expresa ni en el citado artículo 2 ni en la exposición de motivos del RDL 8/2020 de 17 de marzo, y a falta de imposición jurisprudencial concluye que esta ha de ser la de improcedencia. Además, porque tal se deduce de la aplicación de la doctrina jurisprudencial consolidada preexistente en referencia a los despidos sin causa. Porque la declaración de nulidad queda reservada para los supuestos previstos en la ley, relacionados con vulneración de derechos fundamentales o despidos colectivos actuados con mala fe negocial. Y porque el artículo 2 
del RLD 9/20 no introduce una prohibición de despido, sino que se limita a apuntar que les causes de fuerza mayor o ETOP, derivadas de la crisis COVID 19, pueden justificar un ERTE pero no un despido, añadiendo a modo de conclusión que «un despido sin causa es improcedente, pero no nulo. (STSJ Cataluńa, 31 de marzo de 2021. Rec. 3825/2020)

Hay que tener claro que con la expresión literal «No se podrán entender como justificativas de la extinción del contrato de trabajo ni del despido», que señala el artículo 2 del RDL 9/2020, significa que la COVID-19 no pueden fundar esas decisiones extintivas en los contratos de trabajo. Aquella causa solo justifica y permite decisiones empresariales de ajuste temporal; y que el legislador de excepción ha establecido un rango de preferencias en la aplicación de medidas de flexibilidad, exigiendo la adopción de una de las medidas solo cuando no sea posible adoptar la preferente. Por lo que el orden de prelación de aquellas sería la siguiente: adaptaciones en la forma y tiempo de trabajo; y suspensiones de contratos y reducciones de jornada (González, 2020).

La doctrina, sin embargo, afirma, por una parte, que

la utilización del vocablo «justificativas», unida a la inexistencia de la más mínima referencia la nulidad de la medida, conduce a interpretar que la fuerza mayor y las causas ETOP ex COVID no acreditan las extinciones contractuales. Siendo así aplicando la primera de las interpretaciones, parece que el legislador ha situado el debate en el plano procesa de los efectos del despido, conduciendo automáticamente esta conclusión a la declaración de la improcedencia y descartando con ello la nulidad. Si no se justifica la extinción, es que no quede acreditado el presupuesto extintivo por lo que, aplicando el artículo 55 de la ley sustantiva, en relación con el artículo 108 de la Ley Ritual, la consecuencia no puede ser sino la de la declaración de la improcedencia la medida, al quedar reservada en la norma la declaración de nulidad para otros supuestos. (De Castro, 2020)

Por otra, el aludido precepto del RDL 9/2020

no excluye de su ámbito de aplicación a las extinciones de los contratos temporales. Carecerán de justificación cuando las causas reales sean la fuerza mayor o las causas ETOP relacionadas con el COVID-19. Por lo tanto, en sentido contrario, sí es válida la extinción de los contratos temporales cuando no se funda en las causas COVID-19. Es decir, la extinción será posible por otras causas distintas a las señaladas en el artículo 2 del RDL 9/2020, incluyendo la terminación natural o regular del contrato temporal, el despido disciplinario o cualquier otra no relacionada con el COVID-19. (González, 2020; 350)

Por último,

si algo ha hecho la pandemia es poner al descubierto, agudizándolas, debilidades estructurales de nuestro mercado de trabajo que deben ser afrontadas con decisión en 
los próximos tiempos (...) Las medidas de urgencia diseñadas para combatir el impacto del covid-19 en el sistema económico y en el mercado de trabajo no deben contaminar, hasta el punto de desvirtuarlo, el ambicioso programa de reformas que precisa nuestro sistema de relaciones laborales, cuyo marco institucional viene presentando síntomas preocupantes de agotamiento y obsolescencia, en algunos aspectos, desde la primera versión del Estatuto de los Trabajadores de 1980. (Cavas, 2020; 143)

Con todo lo analizado en este estudio, y como reflexión final, se infiere que la respuesta que tendrá que dar el Tribunal Supremo a todas las incógnitas, en cuanto a las limitaciones de los despidos vinculados a la COVID-19 — conforme el artículo 2 del RDL 9/2020 - es de improcedente, y no la nulidad de los despidos. Ahora solo queda esperar que el Alto Tribunal se pronuncie.

\section{Bibliografía}

Agustí Maragall, Joan (2020) «La extinción del contrato en el marco del COVID-19 y su calificación judicial». Jurisdicción Social. Revista de la Comisión de lo Social de Juezas y Jueces para la Democracia, núm. 216.

Aranaz, Jorge (2021) «¿A qué despidos afecta la prohibición de despedir por COVID?». Artículos: Cuatrecasas web, 9 de abril de 2021.

Beltrán de Heredia Ruiz, Ignasi (2020) «La prohibición de despido del art. 2 del RDLey 9/2020 no acarrea nulidad. (Comentario crítico a la SJS/3 Sabadell 6/7/2020)». Una mirada critica a las relaciones laborales. Blog de Derecho del Trabajo y de la Seguridad Social, 22 de julio de 2020.

Baylos GraU, Antonio (2020) «La prórroga del estado de alarma y medidas laborales adicionales de garantía del empleo en la crisis del COVID-19». Blog Según Antonio Baylos..., 28 de marzo de 2020.

Blasco Pellicer, Ángel; López Balaguer, Mercedes y Ramos Moragues, Francisco (2020) Esquemas Eres y Ertes. Tirant lo Blanch: Valencia.

Cabeza Pereiro, Jaime (2020) «ERTE y garantía de ocupación: incertidumbres y certezas». Revista de Trabajo y Seguridad Social. CEF, núm. 456.

Cavas Martínez, Faustino (2020) «Los expedientes de regulación temporal de empleo por COVID-19». Revista de Estudios Jurídico Laborales y de Seguridad Social, núm. 1.

Cruz Villalón, Jesús (2021) «El despido injustificado por COVID», Blog del autor, 2021.

De Castro Marín, Emilio (2020) ¿Resulta viable la declaración de nulidad de las extinciones contractuales y despidos en el contexto del Covid 19 ex art. 2 del RDL 9/2020?. Diario La Ley, núm. 9694.

Falguera Baró, Miguel (2020) Los ERTEs en la legislación extraordinaria derivada de la crisis sanitaria. Bomarzo: Albacete.

GonzÁlez GonzÁLEz, Carlos (2020) ERTES y la transición a los despidos por necesidades empresariales. Consecuencias ante la crisis de la COVID-19. Thomson Reuter-Aranzadi: Cizur Menor.

GonzÁlez González, Carlos (2021) «Las consecuencias jurídicas del incumplimiento de la "prohibición" de despedir por las causas COVID-19". Revista Aranzadi Doctrinal, núm. 4. 
López Hormeño, María Carmen (2021) «La prohibición de despedir durante el Covid-19. ¿Despido nulo o improcedente?», Diario La Ley, núm. 9818, Sección Tribuna, 25 de marzo.

Molina Navarrete, Cristóbal (2020) «La pretendida «prohibición de cese laboral» en tiempos de COVID19: "vicios" de una "legalidad (administrativa) sin derecho». Revista de Estudios Jurídico Laborales y de Seguridad Social, núm. 1.

Navarro Cú́llar, Álvaro y Alonso Barrera, Paula (2021) «Límites y restricciones a la extinción de contratos de trabajo durante la crisis sanitaria ocasionada por el COVID-19", Actualidad Jurídica Uría Menéndez, núm. 55.

Grisolía, Julio Armando (2021) «las normas laborales como consecuencia del covid19: DNU 329/2020 (BO 31/3/2020), DNU 332/2020 (BO 1/4/2020), RES. MTESS 279/2020 (BO 1/4/2020), DNU 367/2020 (BO 14/4/2020), DA 591/2020 (BO 22/4/2020) y RES. MTESS 344/20 MTESS (BO 23/4/2020)». Revista del Instituto de Estudios Interdisciplinarios en Derecho Social y Relaciones del Trabajo (IDEIDES) de la Universidad Nacional de Tres de Febrero (UNTREF), núm. 58.

Poquet Català, Raquel (2021) «Despido realizado contraviniendo el artículo 2 del Real Decreto-Ley 9/2020, ¿nulo o improcedente?, Trabajo y derecho: nueva revista de actualidad y relaciones laborales, núm. 74.

Rodríguez-Toubes MuñIz, Joaquín (2019) «La interpretación extensiva de la ley», Derechos y libertades: Revista de Filosofía del Derecho y derechos humanos, núm. 40.

Segalés Fidalgo, Jaime (2021) «A la búsqueda de la nulidad perdida. Bagatelas a propósito del art. 2 del RDL 9/2020", Jurisdicción Social. Revista de la Comisión de lo Social de Juezas y Jueces para la Democracia, núm. 219.

Todoli Signes, Adrián (2020) «Los contratos temporales pueden extinguirse por el Covid19». Argumentos en Derecho Laboral. Blog, 1 de abril de 2020.

Viqueira PÉrez, Carmen (2020) «Acerca de la calificación del despido que vulnera la pretendida 'prohibición de despedir', Revista de Jurisprudencia Social, núm. 9. 